\title{
A STATISTICAL STUDY OF VARIABILITY IN CATCH OBTAINED BY SHORT REPEATED TRAWLS TAKEN OVER AN INSHORE GROUND
}

\author{
By H. Barnes and T. B. Bagenal \\ The Marine Station, Millport
}

(Text-figs. I-3)

\section{INTRODUCTION}

The numerous quantitative studies on various types of fishing gear have always been chiefly directed to the relation between the proportion of size-groups in the sample and in the population, and to the effect of mesh size on this relation. There have been only a small number of controlled experiments on the variability of replicate samples. While the former type of information is fundamental in fishery investigations, the latter, equally necessary, becomes an essential preliminary in a detailed ecological approach to fishery problems, for it is then necessary to know whether hauls taken at different times or in different places have given significantly different catches.

Thompson (I928) considered sampling problems in his extensive haddock investigations. Data are given from two series of hauls (using a 60 or $50 \mathrm{ft}$. otter trawl), each series extending over several days; and he points out that these samples (I hr. trawling, c. 350 fish per catch) gave an adequate representation of the proportion of size-groups. Using logarithmic values of his catches (see below) the coefficients of variation were 27 and $51 \%$ for the two series.

Hickling (1933), using a full-sized trawl and working on hake, also gives data for repeated hauls taken under various conditions, although like Thompson he was more particularly concerned with the size-frequencies in his samples. The coefficient of variation for catches (log values) of hake varied from 25 to $88 \%$, this range including results from R. V. George Bligh and from commercial trawlers.

Gardiner \& Graham (I925) have considered the working error of Petersen's young fish trawl, and the design of these experiments was similar to that of the present work. They counted a number of species in ten replicate hauls and they give coefficients of variation calculated on actual numbers varying from $27 \%$ for Euthemisto compressa to $54 \%$ for Aglantha digitalis. The analysis of variance of their data (log values) using those animals occurring in all samples is given in Table I. 
The mean square for hauls is significant when tested against $H \times S$ and the estimated log standard deviation for a single observation $\sqrt{s_{H}^{2}+s_{H S}^{2}}$ is 0.1936 , corresponding to a coefficient of variation of $56 \%$.

TABLE I

$\begin{array}{cccc}\begin{array}{c}\text { Source of } \\ \text { variation }\end{array} & \begin{array}{c}\text { Degrees of } \\ \text { freedom }\end{array} & \begin{array}{r}\text { Sum of } \\ \text { squares }\end{array} & \begin{array}{c}\text { Mean } \\ \text { square }\end{array} \\ \begin{array}{c}\text { Main effects } \\ \text { Hauls }(H)\end{array} & 9 & \begin{array}{r}0.9835 \\ 28.2730\end{array} & \begin{array}{l}0.1093 \\ 4.7120\end{array} \\ \begin{array}{c}\text { Species }(S) \\ \text { Residual }\end{array} & 6 & & \\ H \times S & 54 & 1.3792 & 0.0255 \\ \text { Total } & 69 & - & -\end{array}$

This present work consists of the analysis of the variability of a series of replicate hauls taken over a prescribed ground with the same gear and as far as possible under controlled conditions. In order that the results shall be of value to other workers it is necessary to describe both the gear and working conditions in some detail.

\section{MeTHODS}

The Gear and Method of Working

A standard type V.D. trawl, as described by Davis (I936, p. I04), was used, the detailed specifications being as follows: doors, $7 \mathrm{ft}$. 3 in. $\times 3 \mathrm{ft}$. $10 \frac{1}{2}$ in.; bridles, 20 fathoms; headline (fitted in part with Phillips's patent plane floats), $54 \mathrm{ft}$.; foot rope, $72 \mathrm{ft}$.; size of meshes, wings 5 in., square 5 in., belly $3 \frac{1}{2}$ in., cod-end 3 in.

The trawl was shot and hauled in the usual manner (Davis, I936) from the M.V. Calanus under the supervision of Captain R. Souter.

\section{The Ground and Working Conditions}

The area trawled was an inshore ground on the east side of Bute, in the vicinity of Scoulag Point (full Kilometre National Grid Reference 26/II60II59). A dan buoy was laid down and each haul was made on a somewhat elliptical course over the ground, starting and returning to the buoy. Positions were also checked by conspicuous objects on the shore. The bottom, which is here a sandy mud at 20 fathoms, shelves towards the centre of the channel. Tidal currents in this area are of the order of $\mathrm{I} \frac{1}{2}$ knots. During the trawling echo-soundings were taken, and are shown in Fig. I, which indicates that each set of hauls was consistently taken over similar ground.

Three series of four replicate hauls were taken. Each haul lasted $30 \mathrm{~min}$.; including shooting and hauling, each set of four hauls, all taken between I0.30 and I $4.30 \mathrm{hr}$., occupied $3 \mathrm{hr}$. The weather conditions during all three series were moderate to good. 

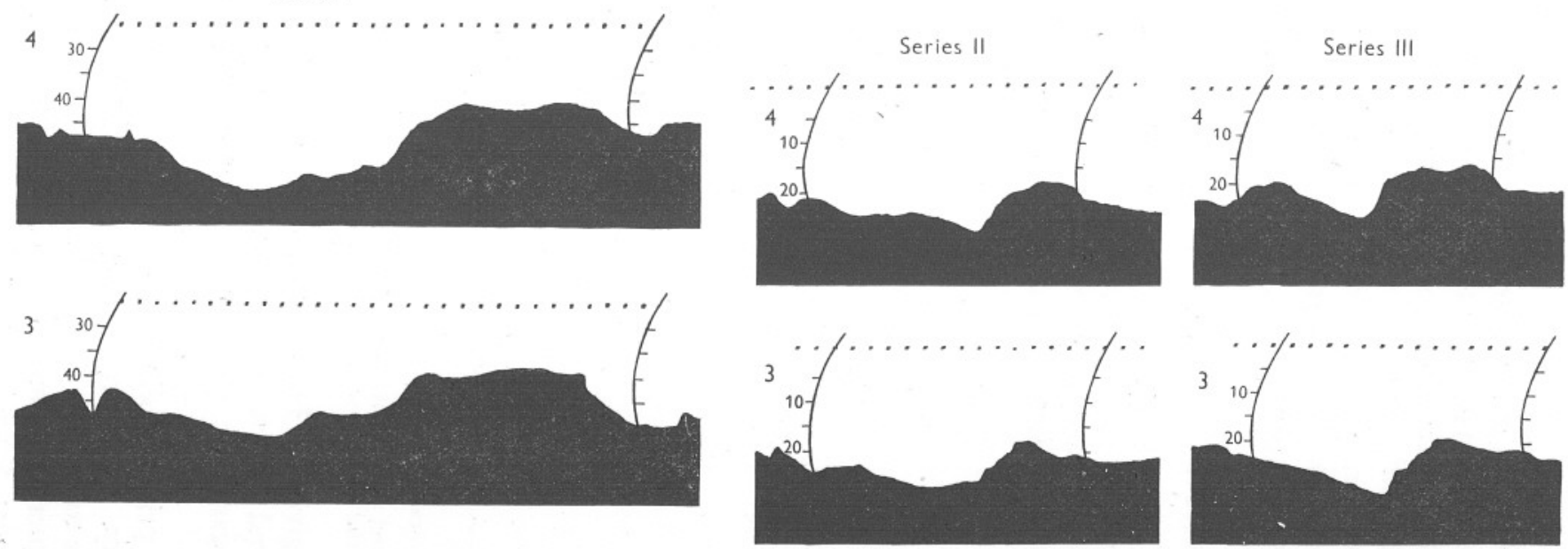

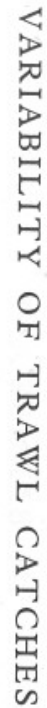
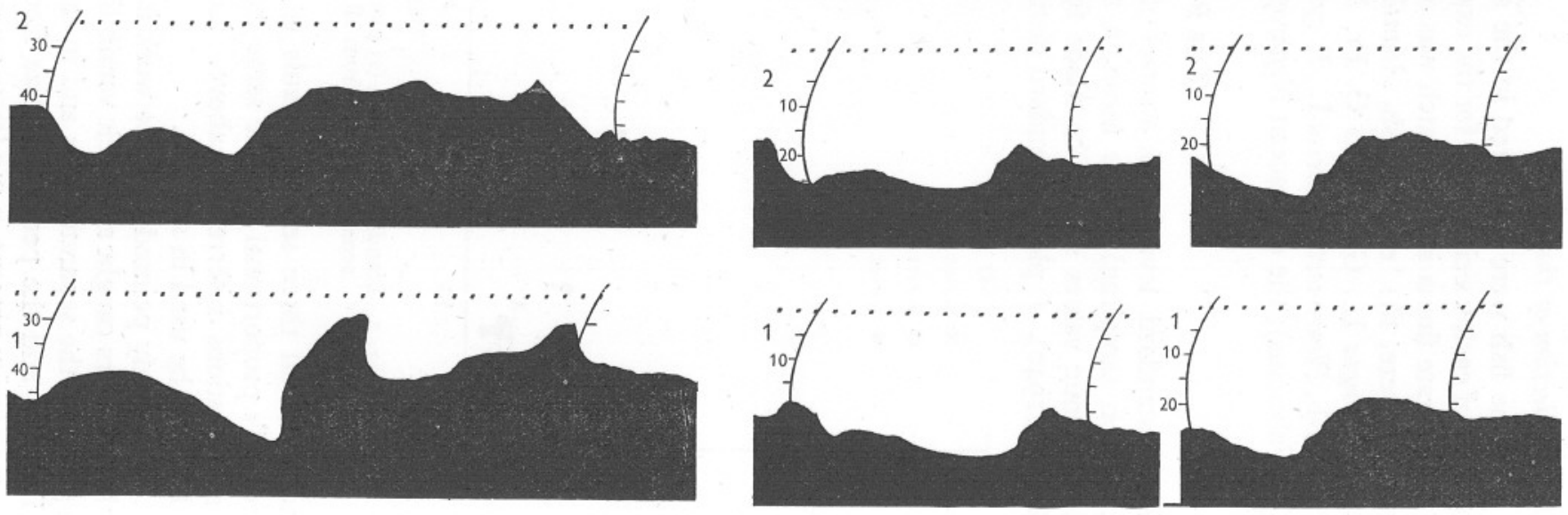

Fig. I. Echo-soundings for hauls I-4, series I-III. Series I time-marks at minute intervals; depth in metres. Series II (the echo-sounder was changed during the experiments) and III time-marks at 2 min. intervals; depth in fathoms. Marks at shooting and hauling. 


\section{The Collection of the Data}

All the fish were measured in the standard manner, and a representative sample of each species taken for the examination of the stomach contents. The invertebrate fauna in each catch was also identified and counted. The major species were, the 'round' fish, Acanthias vulgaris Risso, Gadus callarias L., G. merlangus L., G. minutus O. Fr. Müller, Merluccius merluccius (L.); the 'flat' fish, Pleuronectes platessa L., P. cynoglossus (L.), Drepanopsetta platessoides (O. Fabricius); the crustacean Nephrops norvegicus L.

\section{The Results}

If the standard deviation of a series of catches is roughly proportional (as in plankton sampling) to the mean, a transformation from actual catches to logarithmic values should be made for the analysis of variance (Winsor \& Clarke, 1940). A plot of standard deviation against mean catch for all species

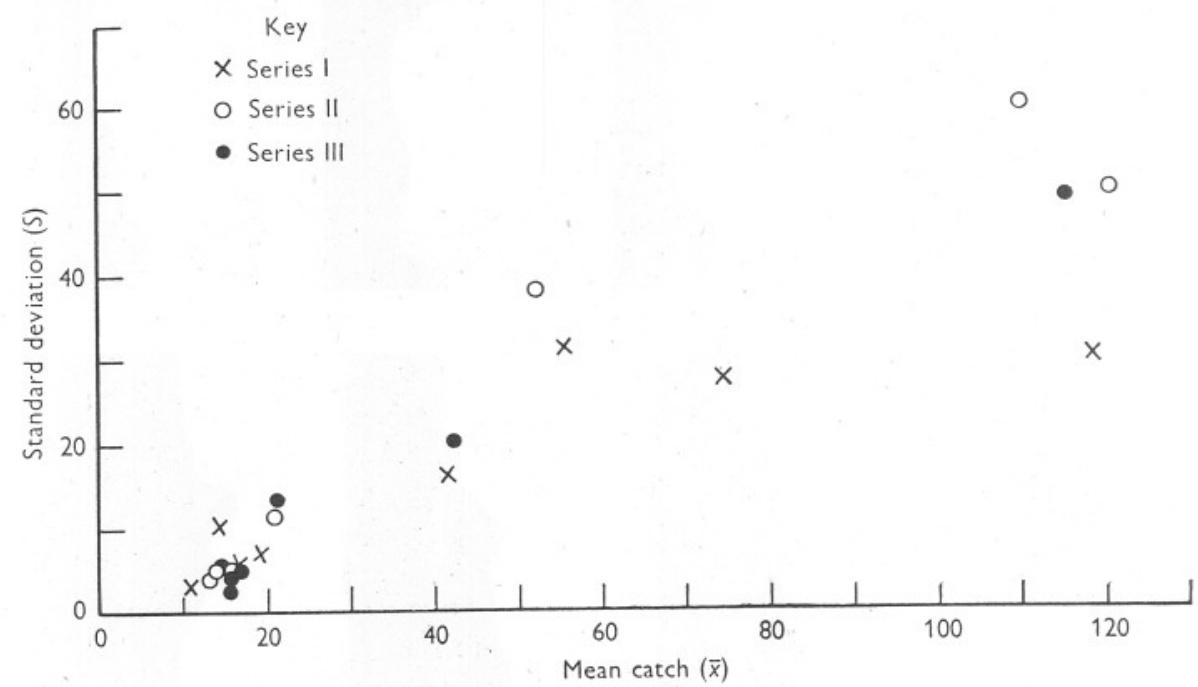

Fig. 2. Standard deviation $(s)$ plotted against mean catch $(\bar{x})$ for each separate species from all the hauls of series I-III.

taken in all three series of hauls is given in Fig. 2. The two values are roughly proportional and the same trend is seen in the results of the earlier investigations referred to above. Logarithmic values of the catches will therefore be used in analysis.

As already pointed out, the work is primarily directed to a comparison of the numbers caught and their variability. However, the mean length for each species in the separate hauls and in the total catch are shown for all series in Table II and the percentage size frequency curves are given in Fig. 3, for some species present in moderate numbers. Since in some the number caught 
Table II. The Mean Length and Grand Mean Length (cm.) for Species in the Separate Hauls COMPRISING SERIES I-III

\begin{tabular}{|c|c|c|c|c|c|}
\hline \multirow[b]{3}{*}{ Species } & \multicolumn{5}{|c|}{ Series I } \\
\hline & \multicolumn{4}{|c|}{ Haul } & \multirow{2}{*}{$\begin{array}{l}\text { Grand } \\
\text { mean }\end{array}$} \\
\hline & I & 2 & 3 & 4 & \\
\hline Dogfish & - & - & - & - & - \\
\hline Cod & $40 \cdot 0$ & $36 \cdot 5$ & $45 \cdot 7$ & $48 \cdot 9$ & $43 \cdot 8$ \\
\hline Whiting & $24 \cdot I$ & 23.8 & $24 \cdot 4$ & $22 \cdot 7$ & 23.8 \\
\hline Poor Cod & $18 \cdot 3$ & 16.3 & 14.2 & 16.0 & $16 \cdot 2$ \\
\hline Hake & 37.6 & $36 \cdot 2$ & $39 \cdot 1$ & $27 \cdot 8$ & $35 \cdot 2$ \\
\hline Plaice & $38 \cdot 1$ & $36 \cdot I$ & $36 \cdot 8$ & $38 \cdot 0$ & $37 \cdot 3$ \\
\hline Witch & 29.4 & $28 \cdot 4$ & $27 \cdot 1$ & $29 \cdot 2$ & $28 \cdot 5$ \\
\hline Long Rough Dab & 20.0 & $20 \cdot 2$ & $20 \cdot 2$ & 19.4 & $20 \cdot 0$ \\
\hline Nephrops & 16.5 & 15.5 & $14 \cdot 2$ & $14 \cdot \mathrm{I}$ & I5. I \\
\hline
\end{tabular}

\begin{tabular}{|c|c|c|c|c|}
\hline \multicolumn{5}{|c|}{ Series II } \\
\hline \multicolumn{4}{|c|}{ Haul } & \multirow{2}{*}{$\begin{array}{l}\text { Grand } \\
\text { mean }\end{array}$} \\
\hline I & 2 & 3 & 4 & \\
\hline $6 \mathrm{I} \cdot 8$ & 60.4 & $6 \mathrm{I} \cdot 9$ & $59 \cdot 2$ & $60 \cdot 8$ \\
\hline $45^{\circ} 0$ & $47 \cdot 6$ & $47 \cdot 7$ & $51 \cdot 5$ & $48 \cdot 0$ \\
\hline $22 \cdot 0$ & $22 \cdot 8$ & $24 \cdot 3$ & $24 \cdot 6$ & 23.4 \\
\hline $15 \cdot 3$ & $19 \cdot 0$ & 19.0 & $17 \cdot 8$ & $17 \cdot 8$ \\
\hline $40 \cdot 9$ & $4 \mathrm{I} \cdot 0$ & $38 \cdot 5$ & $39 \cdot I$ & $39 \cdot 9$ \\
\hline $\mathrm{I} 8 \cdot \mathrm{I}$ & 18.9 & 20.0 & 19.9 & 19.2 \\
\hline 14.0 & $\mathrm{I} 4 \cdot \mathrm{I}$ & 14.0 & 14.2 & I4 $\cdot \mathrm{I}$ \\
\hline
\end{tabular}

\begin{tabular}{|c|c|c|c|c|}
\hline \multicolumn{5}{|c|}{ Series III } \\
\hline \multicolumn{4}{|c|}{ Haul } & \multirow{2}{*}{$\begin{array}{l}\text { Grand } \\
\text { mean }\end{array}$} \\
\hline I & 2 & 3 & 4 & \\
\hline- & - & - & - & - \\
\hline $49 \cdot 9$ & $48 \cdot 7$ & $45 \cdot 4$ & $35 \cdot 8$ & $45 \cdot 0$ \\
\hline $24 \cdot 6$ & 23.3 & $23 \cdot 6$ & 22.5 & 23.5 \\
\hline $39 \cdot 0$ & 35.9 & $35 \cdot I$ & $37 \cdot \mathrm{I}$ & $36 \cdot 8$ \\
\hline $39 \cdot 7$ & $37 \cdot 4$ & $37 \cdot 2$ & $34 \cdot 3$ & $37 \cdot 2$ \\
\hline $28 \cdot 9$ & 26.4 & $26 \cdot 6$ & $26 \cdot 6$ & $27 \cdot I$ \\
\hline 19.0 & 20.5 & $20 \cdot 2$ & 20.9 & $20 \cdot 2$ \\
\hline 15.0 & I 4.9 & 15.5 & 15.7 & $15 \cdot 3$ \\
\hline
\end{tabular}




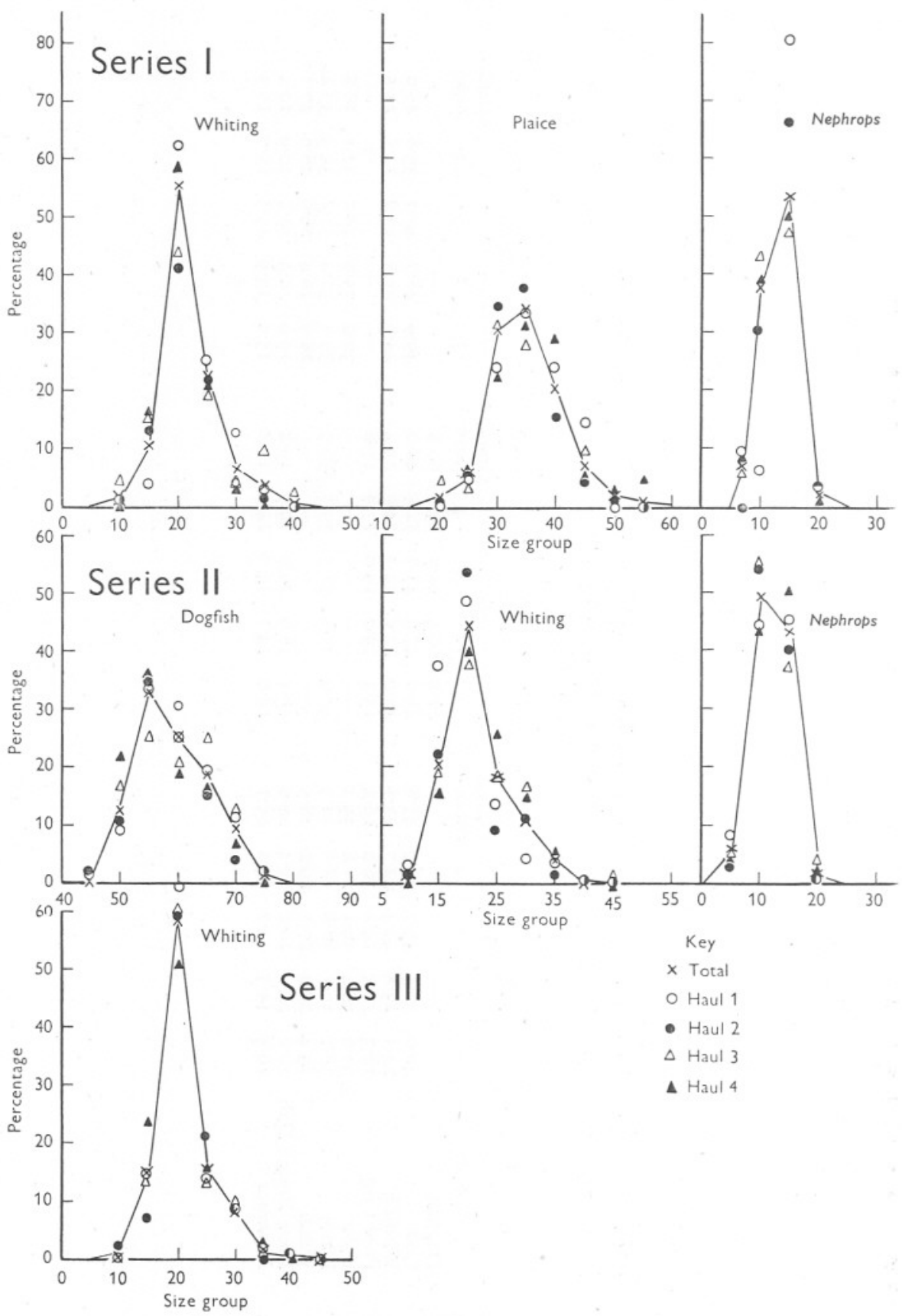

Fig. 3. Percentage frequency distribution of size-groups. Values shown for totals and separate hauls of a given series. 
was small and since in others more than one population (as regards size-groups) was sampled in one haul, quantitative deductions regarding size-frequency in sample and in population have not been made. It is clear, however, that the figure and table strongly suggest that a similar population as regards sizedistribution was being sampled throughout any given series.

\section{Series $I$}

In series $\mathrm{I}$ the species caught in adequate numbers for analysis were the 'round' fish (cod, whiting, poor cod, hake) and the 'flat' fish (plaice, witch, long rough dab) together with Nephrops.

In haul I of this series a moderate number of haddock was taken (39), although in subsequent hauls the numbers of this fish were very small $(2,3,0)$. It is suggested that during part of the first haul a somewhat different ground had been sampled; this suggestion is substantiated both by the occurrence in

\begin{tabular}{|c|c|c|c|}
\hline $\begin{array}{l}\text { Source of } \\
\text { variation }\end{array}$ & $\begin{array}{l}\text { Degrees of } \\
\text { freedom }\end{array}$ & $\begin{array}{l}\text { Sum of } \\
\text { squares }\end{array}$ & Mean square \\
\hline \multicolumn{4}{|l|}{ Main effects } \\
\hline Hauls $(H)$ & 3 & 0.1088 & 0.0363 \\
\hline Species $(S)$ & 3 & $I \cdot 6688$ & 0.5563 \\
\hline \multicolumn{4}{|l|}{ Residual } \\
\hline$H \times S$ & 9 & 0.5334 & 0.0593 \\
\hline \multirow[t]{2}{*}{ Total } & I5 & - & - \\
\hline & \multicolumn{2}{|c|}{ TABLE IV } & \\
\hline $\begin{array}{l}\text { Source of } \\
\text { variation }\end{array}$ & $\begin{array}{l}\text { Degrees of } \\
\text { freedom }\end{array}$ & $\begin{array}{l}\text { Sum of } \\
\text { squares }\end{array}$ & Mean square \\
\hline \multicolumn{4}{|l|}{ Main effects } \\
\hline Hauls $(H)$ & 3 & $0.452 \mathrm{I}$ & 0.1507 \\
\hline Species $(S)$ & 3 & 0.9466 & 0.3155 \\
\hline \multicolumn{4}{|l|}{ Residual } \\
\hline$H \times S$ & 9 & 0.3985 & 0.0443 \\
\hline Total & I5 & - & - \\
\hline
\end{tabular}

this haul only of large numbers of Asterias rubens and Metridium sp., indicating somewhat harder ground, and by the echo-sounding records seen in Fig. I, where the trace of haul I is somewhat different. It is therefore of interest to note that the stomach contents of the haddocks caught in this first haul consisted largely of the remains of Ophiura sp., indicating hard-ground feeding, whereas in contrast, the stomach contents of the species common to all the hauls correspond to the invertebrate fauna of the sandy mud.

The 'round' fish and 'flats' (together with Nephrops) are considered separately. The analysis of variance for 'round' fish is given in Table III. The error variance of a single observation ( $H$ is less than $H \times S)$ is 0.0593 corresponding to a log standard deviation of 0.2436 or a coefficient of variation of $75.3 \%$, for a given species. 
For the second group, 'flat' fish plus Nephrops, the analysis is given in Table IV. The mean square for hauls is not significant and an estimate of the error variance is obtained by pooling $H$ and $H \times S$. This gives the variance of a single observation as 0.0708 or a log standard deviation of 0.2663 , corresponding to a coefficient of variation of $84 \cdot 7 \%$.

The catches of Nephrops were more irregular than the 'flat' fish, and analysis of the latter separately gives a coefficient of variation of $59 \cdot 7 \%$. There were large enough numbers of witch in this series to consider two separate sizegroups, namely greater and less than $25 \mathrm{~cm}$. An analysis of variance of these two size-groups considered by themselves gives a coefficient of variation of $48 \cdot 9 \%$.

\section{Series II}

In this series, taken 6 days later, there was some change in the major species caught. The hake were negligible, whilst large numbers of spur-dogs were taken. The division into 'round' (which includes the latter) and 'flats' plus

\begin{tabular}{|c|c|c|c|}
\hline \multicolumn{4}{|c|}{ TaBle V } \\
\hline $\begin{array}{l}\text { Source of } \\
\text { variation }\end{array}$ & $\begin{array}{l}\text { Degrees of } \\
\text { freedom }\end{array}$ & $\begin{array}{l}\text { Sum of } \\
\text { squares }\end{array}$ & Mean square \\
\hline $\begin{array}{c}\text { Main effects } \\
\text { Hauls }(H) \\
\text { Species }(S)\end{array}$ & $\begin{array}{l}3 \\
3\end{array}$ & $\begin{array}{l}0.3293 \\
1.8083\end{array}$ & $\begin{array}{l}0.1098 \\
0.6028\end{array}$ \\
\hline $\begin{array}{l}\text { Residual } \\
H \times S\end{array}$ & 9 & 0.3596 & 0.0400 \\
\hline Total & $\begin{array}{l}\text { I5 } \\
\text { TABLI }\end{array}$ & - & - \\
\hline $\begin{array}{l}\text { Source of } \\
\text { variation }\end{array}$ & $\begin{array}{l}\text { Degrees of } \\
\text { freedom }\end{array}$ & $\begin{array}{l}\text { Sum of } \\
\text { squares }\end{array}$ & Mean square \\
\hline $\begin{array}{l}\text { Main effects } \\
\text { Hauls }(H) \\
\text { Species }(S)\end{array}$ & $\begin{array}{l}3 \\
2\end{array}$ & $\begin{array}{l}0 \cdot 1178 \\
2 \cdot 1836\end{array}$ & $\begin{array}{l}0.0393 \\
1.0918\end{array}$ \\
\hline $\begin{array}{l}\text { Residual } \\
\qquad H \times S\end{array}$ & 6 & 0.1428 & 0.0238 \\
\hline Total & II & - & - \\
\hline
\end{tabular}

Nephrops has been maintained. For the 'round' fish the analysis of variance is shown in Table V. Again pooling $H$ with $H \times S$ since the former is not significant, gives a mean square of 0.0574 , or a log standard deviation of 0.2396 corresponding to a coefficient of variation of $73 \cdot 7 \%$.

For the second group ('flat' fish plus Nephrops) the analysis of variance is shown in Table VI. The value for $H$ is not significant; pooling gives an estimated error variance of a single observation of 0.0290 , a log standard deviation of 0.1703 and a coefficient of variation of $48 \%$. 
Series $I I I$

In this set dogfish were again absent and haddock were very few, the remaining species being as before, with a noted absence of hard-bottom fauna. Analysis of the 'round' fish is given in Table VII. Again the value for hauls is not significant; the variance of a single observation after pooling is therefore given by 0.0203 , a log standard deviation of 0.1425 and a coefficient of variation of $39 \%$.

\begin{tabular}{|c|c|c|c|}
\hline \multicolumn{4}{|c|}{ TABLE VII } \\
\hline $\begin{array}{l}\text { Source of } \\
\text { variation }\end{array}$ & $\begin{array}{l}\text { Degrees of } \\
\text { freedom }\end{array}$ & $\begin{array}{l}\text { Sum of } \\
\text { squares }\end{array}$ & Mean square \\
\hline \multicolumn{4}{|l|}{ Main effects } \\
\hline Hauls $(H)$ & 3 & 0.0786 & 0.0262 \\
\hline Species $(S)$ & 2 & I.88I 6 & 0.9408 \\
\hline \multicolumn{4}{|l|}{ Residual } \\
\hline$H \times S$ & 6 & $0 \cdot 104 \mathrm{I}$ & 0.0174 \\
\hline \multirow[t]{2}{*}{ Total } & II & - & - \\
\hline & \multicolumn{2}{|c|}{ TABLE VIII } & \\
\hline $\begin{array}{l}\text { Source of } \\
\text { variation }\end{array}$ & $\begin{array}{l}\text { Degrees of } \\
\text { freedom }\end{array}$ & $\begin{array}{l}\text { Sum of } \\
\text { squares }\end{array}$ & Mean square \\
\hline \multicolumn{4}{|l|}{ Main effects } \\
\hline Hauls $(H)$ & 3 & 0.0968 & 0.0323 \\
\hline Species $(S)$ & 3 & 0.5172 & 0.1724 \\
\hline \multicolumn{4}{|l|}{ Residual } \\
\hline$H \times S$ & 9 & 0.3006 & 0.0334 \\
\hline Total & I5 & - & - \\
\hline
\end{tabular}

The analysis with the 'flats' plus Nephrops is given in Table VIII. The value for hauls is less than that for interaction so that the latter may be taken as the required error variance; this is equivalent to a log standard deviation of 0.1828 corresponding to a coefficient of variation of $52 \%$.

\section{Discussion}

The coefficient of variation, which although in the first instance is strictly applicable only to the present results, has been found to vary from 40 to $85 \%$ and this includes values for both 'round' and 'flat' fish. There is no reason, however, to believe that the value is other than adequately representative of this type of sampling of inshore populations. As Winsor \& Clarke (I940) pointed out, with such high log standard deviation it is usually better to work on $\log$ values throughout, but if $2 \sigma$ limits are set from these logarithmic values (see Silliman, I946, for pilchard eggs), then taking $75 \%$ as a representative value for the coefficient and converting to actual catches the fiducial limits would be $30-300 \%$ for a single observation from a single haul. The catches of a given species from two separate hauls could not, on this basis, be considered significantly different unless one was less than a third or greater than three times the other. In attempting to 'contour' fish populations these limits would also be observed. 
The mean catches for all the more abundant species for the three series are given in Table IX. In series I an invasion of haddock into the area, or sampling from a somewhat different ground, has been noted. In the second series there was an incursion of dogfish on to the grounds, the fish being present in reasonable numbers in all four hauls; in contrast to the haddock in series I these dogs were therefore distributed over the whole sampling area. The stomach contents were in an advanced state of digestion, suggesting that they had not been recently feeding on this ground. The cod, whiting, poor cod and hake of the

\begin{tabular}{|c|c|c|c|}
\hline & I & II & III \\
\hline Dogfish & 0 & $52 \cdot 3$ & (I) \\
\hline Cod & 16.5 & 13.8 & 16.5 \\
\hline Whiting & 74.5 & 110.0 & II $5 \cdot 3$ \\
\hline Poor Cod & II 0 & $2 \mathrm{I} \cdot \mathrm{O}$ & (I2) \\
\hline Hake & 14.5 & (9) & 15.8 \\
\hline Plaice & 56.5 & I 4.0 & 42.5 \\
\hline Witch & $4 \mathrm{I} \cdot 8$ & (8) & 14.5 \\
\hline Long Rough Dab & $19 \cdot 3$ & 15.8 & 16.0 \\
\hline Nephrops & 118.5 & $120 \cdot 5$ & $2 I \cdot 3$ \\
\hline
\end{tabular}

\section{TABLE X}

$\begin{array}{cccc}\begin{array}{c}\text { Source of } \\ \text { variation }\end{array} & \begin{array}{c}\text { Degrees of } \\ \text { freedom }\end{array} & \begin{array}{c}\text { Sum of } \\ \text { squares }\end{array} & \text { Mean square } \\ \text { Main effects } & & & \\ \text { Dates }(D) & 2 & 0.1423 & 0.0712 \\ \text { Hauls }(H) & 3 & 0.0108 & 0.0036 \\ \quad \text { Species }(S) & 3 & 5.2682 & 1.756 \mathrm{I} \\ \begin{array}{c}\text { First-order } \\ \text { interactions }\end{array} & & & \\ D \times H & 6 & 0.1106 & 0.0184 \\ D \times S & 6 & 0.5190 & 0.0865 \\ H \times S & 9 & 0.2347 & 0.026 \mathrm{I} \\ \text { Residual } & & & \\ D \times H \times S & 18 & \mathrm{I} \cdot \mathrm{I} 577 & 0.0643 \\ \text { Total } & 47 & - & -\end{array}$

'round' fish have shown a constant population over the whole sampling period of 4 weeks. This is indicated by the results in Table IX, and confirmed by analysis (Table X), using the catches for the three separate dates.

The second-order interaction is high; none of the first-order interactions are significant, and the mean squares for dates and hauls are not significant. The population can therefore be considered unchanged throughout the period. The small value for hauls indicates that no significant changes took place as a result of successive hauls over the 'same' ground.

The greatest differences are shown in the two 'flat' fishes, plaice and witch, and the crustacean Nephrops. The catch of plaice showed a significant fall in series II. Examination showed that the gonads were almost ripe and that the fish had not been feeding; and it was suspected at the time that, as might be 
expected at this season, the fish were moving to deeper water for spawning. However, the catches rose again in series III, and this 'recovery' was maintained in later hauls not given. A similar 'recovery' was also found in the witch and Nephrops. The reason for these changes is not clear, since when compared with the 'round' fish less mobility would be expected in bottomliving species.

These results give no evidence on the origin of the variability in replicate hauls, that is, how much is due to inadequacies of technique and how much is inherent in sampling variation dependent upon the population distribution. It is of interest to note that as with plankton sampling, the standard deviation is roughly proportional to the mean, whilst the variance is greater than and increases with the mean. This suggests that the population is aggregated into groups, so that much of the sampling variation may be inherent in the population distribution, and this problem is now under consideration.

For ecological work, in order to investigate a particular habitat it may be desirable to sample a large number of small areas in a short time. It was for this reason that half hour hauls were made. Comparison of such short hauls has been made with hour hauls, alternating the order of trawling. In view of the high variability of results it is clear that in order to compare the ratio with that expected $(\mathrm{I}: 2)$ it is necessary to have a number of counts. Using the results from a number of trawls, with thirty-two separate values of the ratio the mean was $I: I \cdot 96$. Clearly this value is within the limits expected.

It should be emphasized that the results refer to variations with the same gear tested under as far as possible similar working conditions; it might be expected that the variability with a modified gear would be of the same order. The results provide no information regarding the variations which result when different or modified gear is used over the same ground.

\section{SUMMARY}

The variability in catch of a series of hauls with a V.D. trawl taken under, as far as possible, controlled working conditions has been determined.

For analysis the species were divided into 'round' fish and 'flat' fish together with Nephrops; for both groups the coefficient of variation varied from 40 to $85 \%$. Taking $75 \%$ as a representative value, the $2 \sigma$ fiducial limits are $30-300 \%$ for a single species from a single haul of half an hour duration.

It has been found that the standard deviation is roughly proportional to the mean, and that the variance is greater than the mean and increases with the mean. This suggests aggregation of the population.

The species are considered over the whole sampling period (4 weeks). Except for haddocks and dogfish the 'round' fish constituted a constant population. Changes were found in the other groups and their origin is discussed. 


\section{REFERENCES}

Davis, F. M., 1936. An account of the fishing gear of England and Wales, 3rd ed. Fish. Invest. Min. Agric. Fish., Ser. II, Vol. 15, No. 2, I39 pp.

Gardiner, A. C. \& Graham, M., I925. The working error of Petersen's young fish trawl. Fish. Invest. Min. Agric. Fish., Ser. II, Vol. 8, No. 3, 8 pp.

Hickling, C. F., I933. The natural history of the hake. Part IV. Age determination and the growth-rate. Fish. Invest. Min. Agric. Fish., Ser. II, Vol. I3, No. 2, I20 pp.

Silliman, R. P., I946. A study of variability in plankton townet catches of Pacific pilchard Sardinops caerulea eggs. Fourn. Mar. Res., Vol. 6, pp. 74-83.

Thompson, H., 1928. Haddock biology. V. General features in the biology of the haddock (Gadus aeglefinus L.) in Icelandic waters in the period 1903-1926. Fisheries, Scotland, Sci. Invest., No. v, 63 pp.

Winsor, C. P. \& Clarke, G. L., I940. A statistical study of variation in the catch of plankton nets. Fourn. Mar. Res., Vol. 3, pp. I-34. 